\title{
THE NEO-JURISPRUDENCE OF PIL IN SUPERIOR COURTS OF PAKISTAN: A COMPARATIVE ANALYSIS OF PRE AND POST LAWYERS' MOVEMENT WORKING OF SUPERIOR COURTS
}

Hatim Aziz Solangi $1^{*}$

\begin{abstract}
The dynamics of the superior judiciary in Pakistan have undergone a drastic transformation in its approach and working in post 2007 emergency followed by a landmark movement of civil and legal fraternity for restoration of constitutional supremacy. The neo-jurisprudence is being applauded and criticized at the same time. The excessive use of Suo-motto and public interest litigation at one hand and frequent judicial review of executive and legislative action on other have been the main source of contention between judiciary and other two pillars of state, legislature and executive. The Superior Court is being recognized as the ultimate savior of fundamental rights and guardian of the constitution as well as rights of the people. At the other extreme, the criticism like activist judiciary; disrespect for popular will and making rather interpreting law are most commonly attributed to Superior Judiciary. The study is qualitative in nature and presents a comparative analysis of trends in Superior Court before and after Lawyers' movement. The study also aims in justifying the proactive approach especially in providing social justice on failure of state organs to respond to the exigency of time.
\end{abstract}

Keywords: Public Interest Litigation (PIL); Supreme Court (SC); Jurisprudence; Judicial Review; Social Justice; Supreme Court Monthly Review (SCMR); Pakistan Law Digest (PLD)

\section{Introduction}

Judiciary as one of the three pillars of state occupies an important place and relevance in the socio-political sphere of state. The study attempts to examine the dynamic shift in the working of superior Courts especially its proactive approach towards social justice and rule of law, post imposition of emergency in 2007 followed by restoration of constitution after landmark civil and legal fraternity movement. Judiciary appeared in post 2007 scenario as the ultimate savior of people of Pakistan and they started associating their value judgment with that of decision of superior Courts. The role of Superior Court has become very important and highlighted in wake of state's failure to discharge its fundamental responsibility as enshrined in the constitution. The Judicature also acts as a check over any misadventure by other two organs of state from attempting to transgress their power.

This work is Licensed under a Creative Commons Attribution-Non-Commercial 4.0 International License.

"Hatim Aziz Solangi, Addl. Registrar, ADJ, Sindh High Court. 
The article attempts to help people, lawyers, students of law and other actors to understand and evaluates development of Jurisprudence, the working of superior courts, which is essential for the safeguard of constitutional democracy via viz Constitutional supremacy as against the parliamentary supremacy.

\section{Literature Overview}

Public interest litigation is a newly evolved concept in the modern jurisprudence. Incapacity of traditional system of adjudication; procedural and technical limitation in providing social justice to people at large in wake of concepts of social democracy has given rise to deviation from settled Anglo-Saxon rules and a more relaxed approach is being applied for providing justice to all without taking into account requirements of locus-standi, aggrieved party. A more liberal approach is being applied by the courts to provide social justice by shifting from traditional procedure and commitment to precedent as explained by Prof. Robertson in context of development taking place in Eastern Europe and South Africa. ${ }^{2}$ Such shift in approach of court has resulted in the trend of contemporary rise of judicial power in term of judicial review and corresponding fading away of parliamentary sovereignty. ${ }^{3}$

Public interest litigation is a method to provide speedy and adequate remedies for the violation of fundamental rights of public at large. With recognition of widening the gap between haves and have-nots, the need for providing a platform and a mechanism was never so eminent as is now that could alleviate the miseries of economically and socially deprived sections of society at the hands of privileged few or on account of legislative and executive high-handedness. It is litigation in the interest of public as a whole without taking into account any socio-economic or religio-political orientation. It is a recognized legal action in modern jurisprudence for the enforcement of public interest in the court of law. Public interest is defined as "something in which the public, the community at large, has some pecuniary interest, or some interest by which their legal rights or liabilities are affected. It does not mean anything so narrow as mere curiosity or as the interest of the particular localities, which may be affected by the matter in question". ${ }^{4}$

The rise of public interest litigation is neither of Pakistan origin nor a South Asian phenomenon. While discussing the development emerged in Latin America in the context of Court protecting the individual rights by limiting the governments, author Helmke \& Rios-Figueroa, in their joint work describe Public Interest Litigation as a global phenomenon. ${ }^{5}$ The development of PIL globally and especially in India had great influence upon jurisprudence of superior courts of Pakistan. However, the development was a direct result of recognition of democratic values; the emergence of concepts like social welfare; and adoption of Human Rights Declaration. The PIL is a global movement and not a geographical phenomenon but in South Asia especially in Pakistan it was direct

${ }^{2}$ ROBERTSON, DAVID. "The Nature and Function of Judicial Review." In The Judge as Political Theorist: Contemporary Constitutional Review, 1-39. Princeton; Oxford: Princeton University Press, 2010.

${ }^{3}$ Tom Ginsberg, Judicial Review in New Democracies: Constitutional Courts in Asian Cases (Cambridge: Cambridge University Press, 2003), 3

${ }^{4}$ Black H.C, Black's Law Dictionary ${ }^{\text {th }}$ Ed. Rev. pp. 1469

${ }^{5}$ Gretchen Helmke, and Julio Ríos-Figueroa. "Introduction." Introduction. In Courts in Latin America, edited

by Gretchen Helmke and Julio Rios-Figueroa (Cambridge: Cambridge University Press, 2011), 1-26. 
result of state inaction and lack of will to deliver. The Responsibility of judiciary as a guardian of rights of people becomes of prime importance in event of failure of state to deliver according to their constitutional mandate. The legitimacy crisis had also forced the state institutions to use judicial organ as an umbrella for implementing their decisions and policies and ultimately to abandon some of the privileges and powers and to conform the same to the judiciary. ${ }^{6}$

Apart from institutional vacuum; incapacity of traditional judicial system to provide speedy and efficacious remedy for public at large have also become one of the contributing factors towards the excessive use of inherent jurisdiction and powers by superior courts. Courts are sensitized towards changing socio cultural and environmental needs of society and in order to have relevancy law must keep pace with society. ${ }^{7}$ The development of media and easy access to information has been catalyst for development of public interest litigation and it had not only provided access but had made the people generally right-conscious. Media by discharging its obligation of highlighting every issue of social importance had not only made executive and legislature more prone to accountability but on other hand had increased the demand for justice and compensation for wrong. Media has contributed towards the success of judicial activism by reporting the same in electronic and print media. ${ }^{8}$

\section{Research Methodology}

The study is qualitative in nature. The data collected from published books, articles and legal decisions of superior courts of Pakistan. The data has been assessed as well as evaluated and a comparative distinction is drawn in the working and decisions of superior courts in the period before and after 2007 scenario, imposition of emergency followed by a landmark movement of civil and legal fraternity for independence of judiciary.

\section{PIL Jurisdiction in Pakistan: (Pre Movement Period)}

In Pakistan concept of public interest litigation emerged due to constitutional interpretation of Article 199 and Article 184(3) of the Constitution of Pakistan, as well as the developments taking place beyond the borders especially in India. In the case of Mian Muhammad Shahbaz Sharief v Federation of Pakistan, (Supreme Court 2004) the Court had defined two riders for bringing an action within the domain of Article 184(3): firstly, there must be a violation of fundamental rights; secondly, such violation is of nature of pubic importance requiring immediate intervention of the court. ${ }^{9}$ Initially superior courts have interpreted the concept of aggrieved party liberally and had relaxed the Anglo-Saxon concept of locus standi. In the constitutional jurisprudence of Pakistan, Public Interest Litigation (PIL) can be traced back to the case formally known as Benazir Bhutto case

\footnotetext{
${ }^{6}$ Siddiqui, F. Public Interest Litigation: Predictable Continuity in Radical Departure. In The Politics \& Jurisprudence of Chaudhry Court 2005-2013. Cheema, M.H, \& Gilani, I.S (eds). 101. Oxford University Press, 2015.

${ }^{7}$ Anand, K.S. Foreword. In Fifty years of the Supreme Court of India, its Grasp and Reach. S.K.Verma \& Kussum (eds). VIII. New Delhi, Oxford University Press, 2003.

${ }^{8}$ Sathe, S.P. Judicial Activism in India: Transgressing Borders and Enforcing Limit. (Oxford University Press, 2006), 284

${ }^{9}$ Mian Muhammad Shahbaz Sharief v Federation of Pakistan 2004 PLD 583 (SC)
} 
1988. Though for many it cannot be in strict sense be termed as public interest litigation but a petition of pubic importance. In case reported as Miss Benazir Bhutto v Federation of Pakistan and another, (Supreme Court 1988) Benazir Bhutto as Co-chairman of Pakistan Peoples' Party has challenged the election laws which directly affected the PPP and other parties in upcoming elections in year 1988. In response to objection raised on the maintainability of petition on the ground of locus standi, aggrieved party, the apex court had observed that adversarial nature of contemporary litigation was ill-suited for grant of relief to a large number of unidentified litigation by recognizing the limitation of the traditional Anglo-Saxon procedure that has shut the door of justice for the poor and mass. The concept of "aggrieved party" was liberally interpreted and was given new and extended meaning. The Court further held that petitioner had challenged the amendments made in Political Parties Act 1962 to be in contravention of Article 17 \& 25 of the Constitution. The court while adjudicating not only defined the aggrieved party status but it was also observed that effect of sub-section 1 \& 6 of Section 3-B of Political Parties Act 1962 would be an automatic exclusion of political party in case of non-registration. Court observed that Section 3-C of the Act was inserted for limited purpose and the same cease to have any effect and cannot provide an alternate for non-registration under the section. Based on such observation political parties were also adjudged as aggrieved parties. While interpreting Article 184(3) of the Constitution the Court observed that the approach should not be ceremonious observation of rules of interpretation but the approach should be progressive; and should be inspired from the Objective Resolution and the concepts of social justice and democracy as enshrined in Islam. ${ }^{10}$

Within the two years of Miss Benazir Bhutto case the then Chief Justice had taken a SuoMoto notice in the Darshan Masih case which can be described as the first example of public interest litigation in the constitutional jurisprudence of Pakistan. It was a Suo-Moto where a direct cognizance was taken by the Supreme Court under Article 184(3) on a telegram which was converted into a petition. Public Interest litigation in Pakistan is being identified with the exercise of Suo-Moto jurisdiction of Supreme Court. Darshan Masih who belonged to unprivileged class moved the court through telegram stating therein that after court intervention followed by his and his family release, three among them have been abducted by their owner and remaining they are in constant apprehension and fear. They are hiding and living like animals without food and shelter and requested to let them live like humans. The Court after taking the cognizance issued notice and started hearing the case to solve the problems of bounded labour and new mechanism of systematic inquiry as against adversarial system started in the constitutional jurisprudence of superior courts in case of Darshan Masih v The State, (1990 Supreme Court). The court further observed that procedural necessities can be given out in case of violation of fundamental human rights. ${ }^{11}$

The then Chief Justice Mr.Justice Afzal Zulla who had taken the notice of telegram of Darshan Masih had taken keen interest in the field of public interest litigation. It was his dynamic approach and efforts which made Quetta Declaration possible which was a milestone in the evolution and development of PIL in Pakistan, the commitment of the

${ }^{10}$ Miss Benazir Bhutto v Federation of Pakistan and another 1988 PLD 388 (SC).

${ }^{11}$ Darshan Masih $v$ The State 1990, PLD 513 (SC) 
social justice to society as a whole. ${ }^{12}$ The Supreme Court not only assumed a new jurisdiction but had relaxed the procedural constraints of adversarial system for alleviating the miseries of unprivileged class and to protect the fundamental rights of economically deprived sections of the society.

The apex court of Pakistan in its landmark judgment known as Shahla Zia case having international recognition, have interpreted the concept "right to life" and observed that right to clean environment is a fundamental right of all citizens of Pakistan falling under right to life and right to dignity as provided in Article $9 \& 14$ of the Constitution while acknowledging the importance of Rio Declaration on Environment. ${ }^{13}$

A new platform was provided to people where action of executive as well as legislature was open to scrutiny. Judicial power being characterized with a new people oriented profile and constitutional movement gained the status of social movement. ${ }^{14}$ The development of public interest litigation has resulted in development of corresponding tools like extended meaning of aggrieved person, widening the scope of locus standi, softening the law of limitation, relaxing procedure as well as precedent and Suo-Moto jurisdiction.

\section{Development Post Lawyer Movement}

Superior courts being the guardians of fundamental rights of peoples of Pakistan had adopted unprecedented proactive approach for protecting the fundamental rights of the people. Creation of Human Rights Cell in Supreme Court was catalyst in development of PIL. Though it was established in early 90s but revitalized during the tenure of then Chief Justice of Pakistan, Mr. Justice Iftikhar A Choudhary and reached its zenith after lawyers' movement. The PIL by invoking Article 184(3) of the constitution were of various procedural forms namely human rights cases, complaints converted into constitution petitions, Suo-Moto cases and C.Ps filed on Original Side by individuals or social groups on issues of gross violation of fundamental rights and of public importance. Over the period Pakistan apex courts have spread the new jurisprudence of PIL which is a result of drastic change and radical departures, both on procedure as well as on domain.

The paradigm shift in the approach of apex courts can be visualized from its efforts over the period in breaking the shelf of judicial subservience and in acquiring the status of guardian of constitutional supremacy. The apex courts in Pakistan started enjoying sanctuary not only from constitutional guarantee but also associated itself with the public legitimacy. The people at large have started attaching their value judgment with judiciary and in wake of increasing public legitimacy the societal transformation through judicialization of socio-political issues has become new priority of superior courts. In the words of Justice S.K Anand, the former Chief Justice of India: "it is because of public

\footnotetext{
${ }^{12}$ Address of Chief Justice of Pakistan known as Quetta declaration PLD 1991 Journal 126

${ }^{13} \mathrm{M} / \mathrm{s}$ Shahla Zia \& Others $v$ WAPDA 1994, PLD 692 (SC).

${ }^{14}$ Baxi, P. The Avatars of Indian Judicial Activism: Exploration into Geographies of Injustice. In Fifty years of the Supreme Court of India, its Grasp and Reach, S.K.Verma \& Kussum (eds). (New Delhi, Oxford University Press, 2003), 157
} 
opinion that higher judiciary in country occupies the position of pre-eminence among the three organs of state." 15

\section{A Comparative Analysis}

There have been dynamic transformations in working of superior courts in context of procedural requirements in post lawyers' movement. The requirements as to correct form of procedure involved in pleading are no more relevant. The intent of complaint becomes more important than the contents and its structure. The requirements as to pleadings as well as that of petitioner have become secondary which was condition precedent in formative phase of development of PIL jurisdiction in Pakistan. In case of Muhammad Yaseen v Federaton of Pakistan (Supreme Court 2012) Court affirms that exercising the jurisdiction is not dependent upon existence of petitioner. ${ }^{16}$ The requirement of representative petitioner has become legally irrelevant while deciding the issue before the superior courts in exercise of its original jurisdiction. In case of Khawaja Muhammad Asif $v$ Federation of Pakistan and others (Supreme Court 2013) Court observed that jurisdiction under Article 184(3) can be exercised even without existence of petitioner when information is brought in notice of the court which justifies the exercise of jurisdiction. Court observes this when Khawaja Muhammad Asif showed his inability as petitioner to pursue the petition on becoming Federal Minister. ${ }^{17}$

Supreme Court in a post movement scenario had even relaxed the maintainability bar while exercising the original jurisdiction which used to be the condition precedence for invoking the remedy before the superior courts. While exercising the original jurisdiction superior courts have always honoured the maintainability bar and for invoking the jurisdiction under Article 184(3), the petitioner was required to satisfy the court that there is no other efficacious remedy available. In a new jurisprudence the condition of efficacious remedy either available or not is no more a bar. The bar as to lis pendens as well as the previous precedence and decisions of the courts which had attained finality had become out of consideration. In order to provide effective social justice the procedural and structural constraints of judicial hierarchy were overcome and objections that the matter is either pending at different forums competent to try and adjudicate the controversy or the bar as to matter which had already been substantially decided before another forum competent to try such controversies were overruled. Such departure can be seen in complaint against establishment of Macro Habib Store on the playground. ${ }^{18}$

In the aftermath of restoration of supremacy of constitution post 2009 lawyers movement the concepts like judicial restraints, separation of power and political question doctrine took the backseat. The bar to justiciability of certain controversies or the matter which were otherwise constitutionally committed to other institutions was of no relevance when

${ }^{15}$ Anand, K.S. Foreword. In Fifty years of the Supreme Court of India, its Grasp and Reach. S.K.Verma \& Kussum (eds). VIII. New Delhi, Oxford University Press, 2003.

${ }^{16}$ Muhammad Yaseen v Federation of Pakistan through Secretary Establishment and others 2012, PLD 132 (SC).

${ }^{17}$ Khawaja Muhammad Asif v Federation of Pakistan \& Others, CPC No.05/22 of 2011 order dated

4.12.2013.

${ }^{18}$ Suo Moto Case No.10 of 2009: Complaint Regarding Establishment of Makro Habib Store on Playground, [2010] SCMR 885 (20.10.2009). 
the matter is of public importance requiring immediate intervention of superior courts. The questions/controversies which used to be non-justicible and courts have usually in the past declined to interfere in the matter are no more immune. Foreign policy issues, economic matters and matters of policy issues which were previously on account of question of justicibility not entertained for lack of professional qualifications, resources and institutional incompetence are being taken up and decided in post lawyers' movement era. (Suo Moto Case NO.04 of 2010) In a matter involving political question, the then Prime Minister Syed Yousuf Raza Gillani was prosecuted in a contempt proceedings ${ }^{19}$ and attended the hearings arising out of a petition in case of Dr.Mubashir Hassan \& Others v Federation of Pakistan \& Others (Supreme Court 2010) ${ }^{20}$

Many a matters involving issues having socio-economic bearing on public at large were taken up and decided in contemporary jurisprudence ignoring the justicibility bar. Supreme Court has taken the cognizance and reviewed the executive decision with respect to rental power plants ${ }^{21}$ privatization of Steel Mills, electricity price hype and load shedding. ${ }^{22}$

One of the important aspects of the Neo-jurisprudence which is also post 2009 scenario in the domain of public interest litigation was the notice of mega corruptions in the society. Supreme Court has taken suo moto notices of Corruption in Hajj arrangements ${ }^{23}$; corruption in rental power plants ${ }^{24}$; Violation of Public Procurement Rules 2004 by National Insurance Company limited involving loss of large scale public exchequer. ${ }^{25}$ Superior Court had not only taken strict action against corruption but had also ensured that its directions are properly implemented and complied with, for instance Contempt proceedings against Yousuf Raza Gillani Prime Minister of Pakistan ${ }^{26}$; and Suo-Moto on privatization of Steel Mills. ${ }^{27}$

Previously the superior courts had declined to interfere in open ended cases and usually tried and decided the primary issues in litigation. This aspect had also undergone a transformation in the contemporary scenario. The jurisdiction of public interest litigation was even stretched to open ended cases and all the connected and secondary issues were taken up and decided with the main issue irrespective of the fact that those issues were initially agitated or not. Many a cases involving large scale law and order situation especially in Karachi and Baluchistan in a matter known as Watan Party \& Others $v$ Federation of Pakistan \& Others, (Supreme Court 2011) ${ }^{28}$ and question of missing

\footnotetext{
${ }^{19}$ Suo Motu Case NO.04 of 2010: Contempt Proceedings against Syed Yousuf Raza Gillani, the then Prime Minister of Pakistan 2010, PLD 553 (SC).

${ }^{20}$ Dr.Mubashir Hassan \& Others v Federation of Pakistan \& Others 2010, PLD 265 (SC).

${ }^{21}$ Human Rights Case No. 7734-G of 2009 \& $1003-G$ of 2010 \& 56712 of 2010

${ }^{22}$ Human Rights case No.14392 of 2013 and 790-G of 2009

${ }^{23}$ Suo Motu case No.24 of 2010

${ }^{24}$ Suo moto Human Rights Case No. 7734-G of 2009 \& 1003-G of 2010 \& 56712 of 2010

${ }^{25}$ Suo-moto Case No.18 of 2008

${ }^{26}$ Suo Motu Case NO.04 of 2010: Contempt Proceedings against Syed Yousuf Raza Gillani, the then Prime

Minister of Pakistan 2010, PLD 553 (SC).

${ }^{27}$ (Suo-Moto case No.15 of 2009).

${ }^{28}$ Watan Party \& Others v. Federation of Pakistan \& Others, 2011 PLD 997 SC.
} 
persons ${ }^{29}$ were taken up and decided wherein not only primary issues were dealt with but all secondary and subsequent developments were taken up and decided.

Apex Courts in Pakistan have also developed a new area of jurisdiction where implementing benches were being formed for implementation of the orders passed in such PIL cases. Many of the cases were open ended where continuous mandamuses are being issued and the proper check through these implementing benches were being ensured.

An overview of Annual report of Supreme Court of Pakistan ${ }^{30}$ reveals the confidence general public pose towards superior court in providing social justice. The report depicts a drastic increase in the institution and disposal of Public Interest Litigation. Human Right cases have become a new priority for Supreme Court.

Year-wise Institution and Disposal of HR Cases before Supreme Court

\begin{tabular}{|l|r|r|r|r|}
\hline Year & Opening Balance & \multicolumn{1}{l|}{ Institution } & \multicolumn{1}{l|}{ Disposal } & \multicolumn{1}{l|}{$\begin{array}{l}\text { Current } \\
\text { Balance }\end{array}$} \\
\hline 2008 & 0 & 81 & 81 & 0 \\
\hline 2009 & 0 & 9879 & 3095 & 6784 \\
\hline 2010 & 6784 & 59878 & 51756 & 14906 \\
\hline 2011 & 14906 & 48388 & 47024 & 16270 \\
\hline 2012 & 16270 & 42999 & 45334 & 13935 \\
\hline 2013 & 13935 & 48738 & 41648 & 21025 \\
\hline 2014 & 21025 & 29372 & 38908 & 11489 \\
\hline 2015 & 11489 & 27843 & 28806 & 10526 \\
\hline 2016 & 10526 & 29259 & 30124 & 9661 \\
\hline 2017 & 9661 & 29892 & 31101 & 8452 \\
\hline 2018 & 8452 & 105847 & 88546 & 25753 \\
\hline 2019 & 25753 & 18463 & 41107 & 3109 \\
\hline
\end{tabular}

Upto $31.05 .2019^{31}$

${ }^{29}$ President Baluchistan High Court Bar Association v Federation of Pakistan \& Others, 2012 SCMR 1958 (12.10.2012)

${ }^{30}$ Supreme Court of Pakistan, Annual Report 2018-19: Human Right Cell. SC (Islamabad: SC, 2020), 76-79 https://www.supremecourt.gov.pk/downloads_judgements/all_downloads/annual_reports/SCP_Annual_Report -2018_2019.pdf

${ }^{31}$ Ibid. 
Year-wise Institution \& Disposal of HR cases

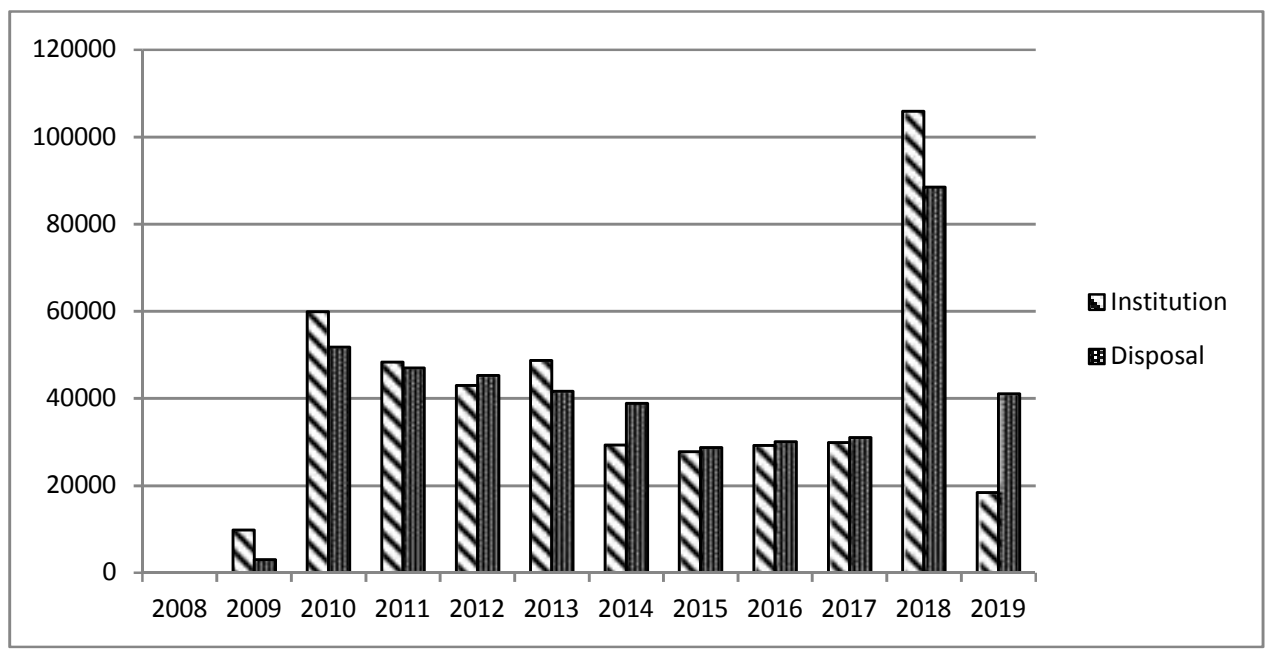

Year-wise Institution of HR cases

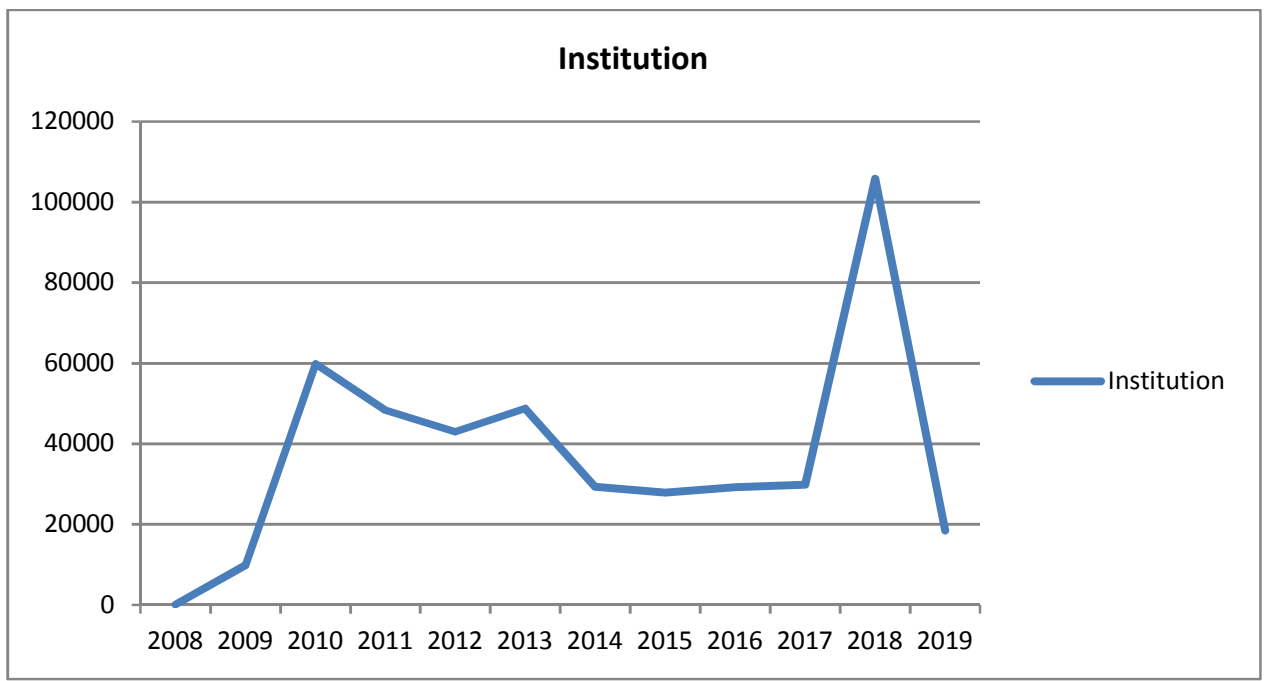

The graph as per extract of Supreme Court Annual Report ${ }^{32}$ clearly demonstrates the importance of Human rights cases, Public Interest litigation in the working of Superior Court. However, with the increase of Suo Moto Jurisdiction and PIL, the rhetoric of Judicial Activism proportionally rises within some judicial discourse and within political and executive platform. The Judicial overreach on political-institution issues, the mandate

\footnotetext{
${ }^{32}$ Ibid.
} 
of which is otherwise explicitly fall within the domain of other institution, is a criticism associated with the working of Superior Court as against the separation of power.

\section{Conclusion}

The constitutional history and its development in context of role of judiciary have remained shrouded with the clouds of theory of necessity which culminated into jurisprudence of Pakistan. Resultantly many military interventions were witnessed and most of the executive actions remain immune from judicial review. The constitutional history of Pakistan had been like pendulum swinging from one extreme to another. Despite many anomalies the superior courts in Pakistan have succeeded in forming an image of last savior for the people of Pakistan as Guardian of their rights. The success of lawyers' movement culminated into restoration of judiciary and in reinstatement of the then Chief Justice Iftikhar Muhammad Choudhary along with 42 of his fellow judges. In consequence thereof, the societal transformation through judicialization of socio-political issues had become the new priority for the superior courts. This phenomenon of judicialization of politics and the new emerging traits within contemporary democracy were explained by Guarnieri and Pederzol, in Western European judiciary, in the words as: "....Nothing that the social and political significance of the judiciary has become common trait of contemporary democracy: A phenomenon described as judicialization of politics. Resultantly judges participation in politic has risen: from the elaboration of public policies as a result of implementation of laws and the review of their constitutionality, to their implementation by means of the judiciary's overview of administrative agencies". ${ }^{33}$ One of the main defence offered by judicial power as explained by Ely that the court is especially necessary to protect from subversion or erosion of constitutional rights of all individuals. ${ }^{34}$ In the words of Choper (Choper, 1980) "if judicial power were both independent and well defined the judges learning and integrity would effectively prevent the erosion of public liberty". ${ }^{35}$

Judicial Review in contemporary World can not fit well in orthodox separation of Power Model. Constitutional Courts perform more than the judicial function domain as traditionally enjoined with. Constitution has turned merely law of the land to a dynamic and living document as the true picture of peoples aspiration embodying the values and principles of society. Court by virtue of Constitutional Power of Judicial Review has taken the task of realizing such values as provided in the Constitution.

An indisputable important role is being performed by superior court through the weapon of PIL in its struggle to ensure social justice, yet many doubt its capacity to achieve the desired result on account of very nature of the process/undertakings i.e. litigation. Critics believe that social institution cannot be reformed through litigation, which is otherwise a complex phenomenon, and on the other hand over reliance on Court would ultimately

\footnotetext{
${ }^{33}$ Carlo Guarnieri \& Patrizia Pederozli, The Power of Judge: A Comparative Study of Court and Democracy. Tomas, C.A (eds). (Oxford University Press, 2002)

${ }^{34}$ John Hart Ely, Democracy \& Distrust: A theory of judicial review (Cambridge: Harvard University Press, 1980), 102 .

${ }^{35}$ Jesse H, Choper, Judicial Review and the National Politics Process (Chicago: University of Chicago Press, 1980), 2, 68, 69.
} 
undermine other political institution. Despite Criticism and imperfection yet such public interest litigation is indispensable strategy of social change and has considerably contributed towards wellbeing of general public.

\section{Bibliography}

Anand, K.S. (2003). Fifty years of the Supreme Court of India, its Grasp and Reach, S.K.Verma \& Kussum (eds). New Delhi, Oxford University Press, 2003.

Baxi, P. The Avatars of Indian Judicial Activism: Exploration into Geographies of Injustice. In Fifty years of the Supreme Court of India, its Grasp and Reach, S.K.Verma \& Kussum (eds). New Delhi, Oxford University Press, 2003.

Black, Henry Campbell. Black's Law Dictionary. West Publishing Company, Revised Fourth Edition, 1971.

Choper, J H. Judicial Review and the National Politics Process. Chicago: University of Chicago Press, 1980.

Darshan Masih v The State 1990, PLD 513 (SC), (Petition: 1 of 1988).

Dr.Mubashir Hassan \& Others v Federation of Pakistan \& Others 2010, PLD 265 (SC).

Ely, J.H. Democracy \& Distrust: A theory of judicial review. Cambridge: Harvard University Press, 1980

Ginsberg, Tom. Judicial Review in New Democracies: Constitutional Courts in Asian Cases. Cambridge: Cambridge University Press, 2003.

Guarnieri, C \& Pederozli, P. The Power of Judge: A Comparative Study of Court and Democracy. Tomas, C.A (eds). Oxford University Press, 2002.

Helmke, Gretchen, and Julio Ríos-Figueroa. "Introduction." Introduction. In Courts in Latin America, edited by Gretchen Helmke and Julio Rios-Figueroa, 1-26. Cambridge: Cambridge University Press, 2011.

Human Rights Case No. 7734-G of 2009 \& 1003-G of 2010 \& 56712 of 2010: Alleged Corruption in Rental Power Plants. [2012] SCMR 773 (30.03.2012),

Human Rights Case No.14392 of 2013 and 790-G of 2009: Rise in Electricity price and load shedding.

Khawaja Muhammad Asif v Federation of Pakistan \& Others, CPC No.05/22 of 2011 order dated 4.12.2013).

M/s Shahla Zia \& Others v WAPDA 1994, PLD 692 (SC). 
Mian Muhammad Shahbaz Sharief v Federation of Pakistan 2004, PLD 583 (SC).

Miss Benazir Bhutto v Federation of Pakistan and another 1988, PLD 388 (SC).

Muhammad Yaseen v Federation of Pakistan through Secretary Establishment and others 2012, PLD 132 (SC).

President Baluchistan High Court Bar Association v Federation of Pakistan \& Others, [2012] SCMR 1958 (12.10.2012);

Quetta Declaration, PLD 1991 Journal 126

ROBERTSON, DAVID. The Judge as Political Theorist: Contemporary Constitutional Review. Princeton; Oxford: Princeton University Press, 2010.

Sathe, S.P. Judicial Activism in India: Transgressing Borders and Enforcing Limit. Oxford University Press, 2006.

Siddiqui, F. Public Interest Litigation: Predictable Continuity in Radical Departure. In The Politics \& Jurisprudence of Chaudhry Court 2005-2013. Cheema, M.H, \& Gilani, I.S (eds). 101. Oxford University Press, 2015.

Suo Motu Case NO.04 of 2010: Contempt Proceedings against Syed Yousuf Raza Gillani, the then Prime Minister of Pakistan 2010, PLD 553 (SC).

Suo Motu Case No.10 of 2009: Complaint Regarding Establishment of Makro Habib Store on Playground, [2010] SCMR 885 (20.10.2009).

Suo Motu case No.24 of 2010: Corruption in Hajj Arrangements in 2010, PLD 2011 SC 963.

Suo-Motu case No.15 of 2009. on Privatization of Steel Mills 2012, PLD 210 (SC).

Supreme Court of Pakistan. Annual Report 2018-19: Human Right Cell. SC. Islamabad: SC, 2020.

Watan Party \& Others v. Federation of Pakistan \& Others (2011), PLD 997 (SC). 